\title{
Chitinase-3-like protein 1 levels in bipolar disorder
}

Basak Sahin, MD, Ikbal Inanli, MD, Ali M. Caliskan, MD, Sema Uysal, MD, PhD.

$$
\begin{aligned}
& \text { ABSTRACT } \\
& \text { الأهداف: تقييم العلاقة بين مستوى تعبير والدور البيولوجي لـ }
\end{aligned}
$$

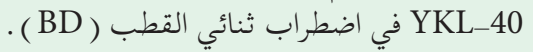

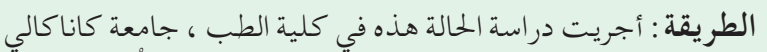

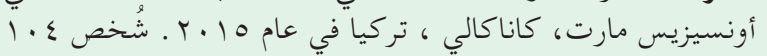

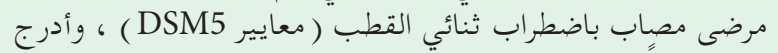

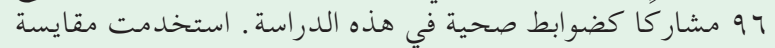

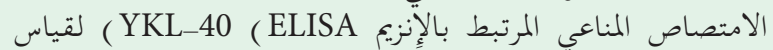

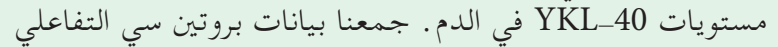

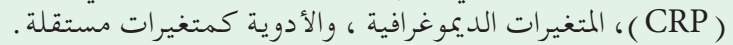

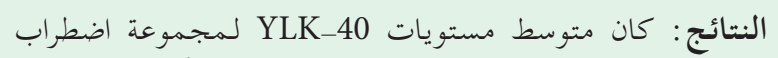

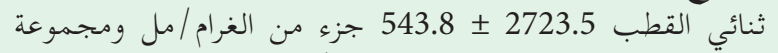

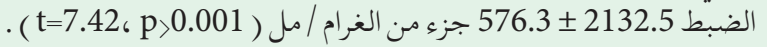

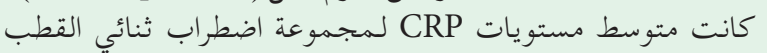

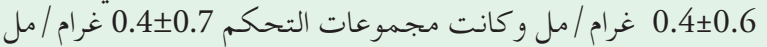

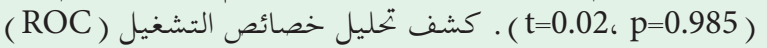

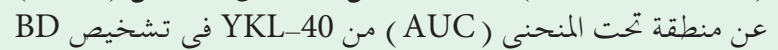

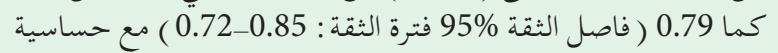

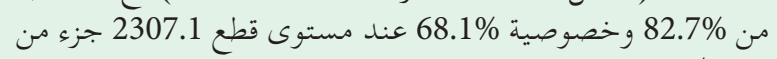

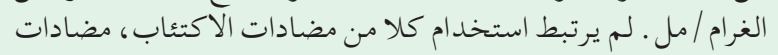

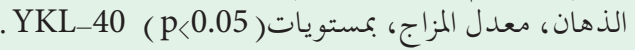

$$
\begin{aligned}
& \text { الخاتمة : مع مستو يات الحساسية والخصوصية المقبولة، يمكن استخدام }
\end{aligned}
$$

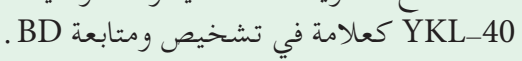

Objectives: To evaluate the relationship between the expression level and biologic role of YKL-40 in bipolar disorder $(\mathrm{BD})$.

Methods: This case-control study was conducted in the Faculty of Medicine, Canakkale Onsekiz Mart University, Canakkale, Turkey in 2015. One hundred and four patients diagnosed as having bipolar disorder (DSM5 criteria), and 96 participants were included as healthy controls in this study. A human YKL-40 enzymelinked immunosorbent assay (ELISA) kit was used to measure the serum YKL-40 levels. As independent variables, we collected data on C-reactive protein (CRP), demographic variables, and medications.
Results: The mean YLK-40 levels for the BD was $2723.5 \pm 543.8 \mathrm{pg} / \mathrm{ml}$ and control groups was $2132.5 \pm 576.3 \mathrm{pg} / \mathrm{ml}(\mathrm{t}=7.42, p<0.001)$. The mean CRP levels for the $\mathrm{BD}$ was $0.4 \pm 0.6 \mathrm{mg} / \mathrm{dl}$ and control groups was $0.4 \pm 0.7 \mathrm{mg} / \mathrm{dl} \quad(\mathrm{t}=0.02, p=0.985)$. The receiver operating characteristics (ROC) analysis revealed an area under the curve (AUC) of YKL-40 in the diagnosis of $\mathrm{BD}$ as 0.79 (95\% confidence interval [CI]: 0.72-0.85) with a sensitivity of $82.7 \%$ and specificity of $68.1 \%$ at a cutoff level of $2307.1 \mathrm{pg} / \mathrm{ml}$. The use of antidepressants, antipsychotics, mood modifiers, and the presence of any comorbidity was not related to the YKL- 40 levels $(p>0.05)$.

Conclusion: With acceptable sensitivity and specificity levels, the YKL- 40 can be utilized as a marker in the diagnosis and follow-up of BD.

Saudi Med J 2019; Vol. 40 (1): 26-32 doi: 10.15537/smj.2019.1.23396

From the Departments of Psychiatry (Sahin), Biochemistry (Uysal), Faculty of Medicine, Canakkale Onsekiz Mart University, Canakkale, and from the Department of Psychiatry (Inanli, Caliskan), Health Sciences University, Konya, Turkey.

Received 17th July 2018. Accepted 30th October 2018.

Address correspondence and reprint request to: Dr. Basak Sahin, Department of Psychiatry, Faculty of Medicine, Canakkale Onsekiz Mart University, Canakkale,Turkey.E-mail: basaksahin@comu.edu.tr ORCID ID: orcid.org/0000-0002-5943-4087

$\mathrm{B}$ ipolar disorder (BD), also known as bipolar mood disorder or manic depressive illness, is a frequent, violent and persistent mental condition. This disease is a serious lifetime battle and challenge. ${ }^{1}$ On the other hand, mental disorders and general medical cases are more prevalent in patients with bipolar disorders than the others. ${ }^{2}$ The pathophysiology of BD has not been described, and no objective biologic markers correspond fairly with the disease degree. Many factors contribute to $\mathrm{BD}$, including genetic, biochemical, neurophysiologic, psychodynamic, and environmental factors. ${ }^{3-7}$ Bipolar disorder is viewed in $0.3-1.5 \%$ worldwide. ${ }^{8}$ 
Human cartilage glycoprotein 39 (HC-gp39) also known as YKL- 40 is a $40 \mathrm{kDa}$ heparin- and chitin-binding glycoprotein, $38-\mathrm{kDa}$ heparinbinding glycoprotein, or chitinase-3-like protein 1 (CHI3L1). ${ }^{9-11}$ Human cartilage glycoprotein 39 (HC-gp39) is produced by activated microglia and reflects inflammatory processes, but its function is not completely known; it is hypothesized to be an agent of the innate immune system, involved in tissue remodeling during inflammation. ${ }^{12-14}$ In some disorders of the central nervous system, the serum YKL-40 level is altered. While YKL-40 expression from astrocytes is seen in neuroinflammatory disorders, an increase of serum and tissue YKL-40 levels were identified in brain tumors, in traumatic brain injury, and in Alzheimer's disease. ${ }^{14-18}$ The diagnosis of $\mathrm{BD}$ endures patient's history and clinical process. Previous study have long explored biological indicators for mental disorders, specially for affective disorders. Frye et al, ${ }^{19}$ found significant difference in 6 proteins associated with bipolar depression, mood disorders, and including unipolar, hemopexin (HPX), growth differentiation factor 15 (GDF-15), matrix metalloproteinase-7 (MMP-7), hepsin (HPN), transthyretin (TTR), and retinol-binding protein 4 (RBP-4). In mood disorders, MMP-7 was significantly different. In bipolar cases (both of BP-I/II) HPN, GDF-15, MMP-7 were significantly different. In BO-1 HPX, GDF-15, RBP-4, TTR, and HPN proteins were all significantly different. These findings inspire that proteomic panels may be useful in defining and distinguishing mood disorders.

This study aimed to investigate the relationship between the expression level and biologic role of YKL-40 in BD.

Methods. This case-control study was conducted in the Medical Faculty, Çanakkale Onsekiz Mart University, Çanakkale, Turkey in 2015. The study reporting was carried out in accordance with the STrengthening the Reporting of OBservational studies in Epidemiology (STROBE) guidelines. ${ }^{20}$ The Local Ethics Committee of Çanakkale Onsekiz Mart University, Turkey approved the study protocol. All participants signed the informed consent and complies with the Declaration of Helsinki.

Disclosure. This study was funded by Çanakkale Onsekiz Mart University Scientific Research and Projects Coordination Unit Çanakkale, Turkey (Contract No: TSA-2015-564).
The Çanakkale Onsekiz Mart University Hospital is located in Çanakkale, Turkey. It is a tertiary-level hospital serving a population of approximately 500 thousand people. The hospital is a teaching and clinical reference center with a 554 bed capacity. The hospital has 33 departments. With 5 assistant professors and 10 residents, the department of psychiatry receives approximately 1000 patients per month.

The participants of the study were patients under follow-up at the department of psychiatry with the diagnosis of $\mathrm{BD}$. The diagnosis of $\mathrm{BD}$ (namely, type I/II or not otherwise specified) was compose by 2 psychiatrists according to the diagnostic and statistical manual of mental disorders, 5th edition, $(\mathrm{DSM}-\mathrm{V}) .{ }^{21}$ All 113 patients under follow-up during the study period were invited to join. Invitations were carried out via phone calls by one of the investigators. Five patients $(4.4 \%)$ could not be contacted despite repeated attempts and $4(2.7 \%)$ rejected to join. None of the participants had any verified inflammatory disease. Healthy relatives and visitors of the study group comprised the control group. The controls were assigned to study by wherever they were waiting for their acquaintances or relatives around the examination room. Participants in the control group were examined by a staff psychiatrist, had never been diagnosed with a psychiatric illness and also confirmed to be healthy. Data of 6 participants in the control group were not included in the analysis due to missing information. All participants filled a sociodemographic data form.

Patients with bipolar disorder diagnosed by at least 2 psychiatrists and volunteers were included in the study. Patients with inflammatory disease and those with additional psychiatric disease were excluded in the study.

Patients with BD were appreciated with the Hamilton depression rating scale (HDRS), and Young mania rating scale (YMRS). ${ }^{22-23}$ Both tools were checked for cross-cultural validity. Cronbach alpha internal consistency coefficients for the Turkish versions of the HDRS were reported as 0.76 and YMRS were reported as 0.75 . The YMRS is a rating scale used to evaluate manic symptoms at baseline and over time in individuals with mania. The HDRS (Ham-D) was used to assess the depressive level of patients. General functions of the patients were used to evaluate with the global assessment of functioning (GAF). ${ }^{24}$ The study variables were age (year), gender, occupation, marital status, education, residence, family history of psychiatric illness, alcohol, smoking, body weight, body mass index (BMI), height, obesity, waist circumference, CRP (mg/dl), GAF score, clinical global impression- 
severity, presence of additional disease; use of mood modifier, dual mood modifier, depot antipsychotic, or antidepressants; polypharmacy, HDRS, and YMRS.

The YMRS has 11 items and is based on the subjective report of patient's clinical condition over the last 48 hours. During the clinical interview, clinical observations based on additional information was noted. Four items graded scale ranging from 0-8 points (including factors as speech, irritability, thought content, disruptive/aggressive behavior) was used in the interview. The other items are graded on a scale ranging from $0-4$. The first 4 items have twice the weight of the other items to compensate for low cooperation by severely ill patients. ${ }^{22}$ The Turkish version of the scale was used in the research. ${ }^{25}$

The HDRS is a tool used to measure the severity of depression among adults by asking questions about suicide ideation, mood, insomnia, feelings of guilt, agitation or retardation, weight loss, somatic symptoms and anxiety. The questionnaire has 17 items, scored on a 3- or 5-point scale, used to compare the relevant descriptor. ${ }^{23}$

Global assessment of functioning is used to evaluate the overall functioning of a person during a specific period of time. The scale ranges in a continuum from psychological/psychiatric ailments to complete health. Global assessment of functioning is scored from 1 (lowest) to 100 (highest) and 0 (inadequate information). ${ }^{24}$

The clinical global impression (CGI) was constructed for a brief clinician's view of the patient's global functioning before and after starting a study medication. The CGI has 2 one-item measures assessing the a) severity of psychopathology from 1-7 and b) change from the implementation of the treatment on a 7 -point scale. ${ }^{26}$

In the questionnaire, there was a brief information about the research to ensure that the research data was obtained correctly, and participants were asked not to put their identities on the questionnaire form. The study and control groups were matched based on age and gender.

Post-hoc sample size calculation demonstrated that to compare YKL-40 between 2 independent groups using the t-test, 96 participants in each group provides a power of $80 \%$ with a sigma of $570 \mathrm{pg} / \mathrm{ml}$ and true difference of means of $234 \mathrm{pg} / \mathrm{ml}$.

Height, weight, and waist circumferences were measured by ordinary instruments used in the hospital. The BMI was calculated by the formula of weight $(\mathrm{kg}) /$ height $\left(\mathrm{m}^{2}\right)$. The waist circumference was measured at the midpoint between the lower margin of the lowest palpable rib and the top of the iliac crest with standard measuring tape wrapped nearly around the patient. Measurement was made with the patient in upright position and the tape parallel to the floor.

Peripheral venous blood samples centrifuged at $4000 \mathrm{rpm}$ for 10 minutes and were stored at $-80^{\circ} \mathrm{C}$ until the serum analyzed and collected after a 12 -hour fasting period. All samples were resolved only once before analyses. A human YKL-40 ELISA kit (Adipobiotech, Santa Clara, USA) did measurements of the YKL-40 levels. The levels of CRP were measured by immunoturbidimetry method.

Statistical analysis. Data was entered into the computer and analyzed using the Statistical Package for Social Science (SPSS) Version 20.0 software (IBM Corp., Armonk, NY, USA). The results were presented as frequencies, percentages, means, and standard deviations (SD). The YKL-40 was set as the dependent variable; its normal distribution was examined by the Kolmogorov Smirnov test. In the comparison of the clinical data and demographics, the independent samples t-test was used for quantitative variables and the Chi-square test for categorical variables. Some associated parameters were investigated by correlation analysis of Pearson's or Spearman's. The diagnostic accuracy of YKL-40 was evaluated with ROC analysis to evaluate diagnostic accuracy of YKL- 40 . A $p$-value of $<0.05$ was considered significant.

Results. In this study, 104 bipolar patients and 96 controls were included. There were no any significant differences in gender, age, occupation, residence, smoking status, and waist circumference among the patient and the control groups. The percentage of widow or divorced was higher in the BD group $14(12.7 \%)$ than in the control group $3(3.1 \%),\left(\chi^{2}=6.6, p<0.04\right)$. The educational level was lower in the BD group than in the control group $\left(X^{2}=33.5, p<0.001\right)$. The percentage of family history of psychiatric illness was higher in the $\mathrm{BD}$ group $41(41 \%)$ than in the control group $17(17.7 \%),\left(X^{2}=10.2, p=0.006\right)$. Measures of obesity such as body weight, BMI, and waist circumference were higher in the $\mathrm{BD}$ group than in the control group $(p<0.05)$. Comparison of sociodemographic variables of controls and patients with BD are given in Table 1 . The mean \pm SD GAF scores were 76.5 \pm 12 .6. Distributions of other features of BD patients are summarize in Table 2.

The mean levels of YLK- 40 for the BD group was $2723.5 \pm 543.8 \mathrm{pg} / \mathrm{ml}$ and control group was $2132.5 \pm 576.3 \mathrm{pg} / \mathrm{ml},(\mathrm{t}=7.42, p<0.001)$. The mean 
CRP levels for the BD group was $0.4 \pm 0.6 \mathrm{mg} / \mathrm{dl}$ and control group was $0.4 \pm 0.7 \mathrm{mg} / \mathrm{dl},(\mathrm{t}=0.02, p=0.985)$.

The use of antidepressants, antipsychotics, mood modifier, and the presence of any additional disease in patients with $\mathrm{BD}$ was not related to the plasma levels of YKL-40 ( $p>0.05)$. The mean levels of YKL-40 of patients not using polypharmacy was $3072.3 \pm 319.5 \mathrm{pg} / \mathrm{ml}$, while those in polypharmacy had levels of $2682.3 \pm 551.1 \mathrm{pg} / \mathrm{ml} \quad(\mathrm{t}=2.30, p=0.02)$ (Table 3).

Table 1 - Comparison of sociodemographic parameters of patients with bipolar disorder and controls.

\begin{tabular}{|c|c|c|c|c|}
\hline \multirow[t]{3}{*}{ Parameters } & \multicolumn{2}{|c|}{ Groups } & \multirow[t]{3}{*}{$P$-value } & \multirow[t]{3}{*}{$\mathrm{t} / \chi^{2}$} \\
\hline & $\mathrm{BD}$ & Control & & \\
\hline & \multicolumn{2}{|c|}{ Mean $\pm S D$} & & \\
\hline Age (year) & $40.5 \pm 13.2$ & $37.6 \pm 13.8$ & 0.124 & 1.54 \\
\hline \multicolumn{5}{|l|}{ Gender } \\
\hline $\begin{array}{l}\text { Female } \\
\text { Male }\end{array}$ & $\begin{array}{l}52 \pm 50.0 \\
52 \pm 50.0\end{array}$ & $\begin{array}{l}59 \pm 61.5 \\
37 \pm 38.5\end{array}$ & 0.103 & 2.65 \\
\hline \multicolumn{5}{|l|}{ Occupation } \\
\hline $\begin{array}{l}\text { No regular work } \\
\text { Employee } \\
\text { Officer } \\
\text { Retired } \\
\text { Housewife }\end{array}$ & $\begin{array}{l}23 \pm 22.3 \\
20 \pm 19.4 \\
12 \pm 11.7 \\
15 \pm 14.6 \\
33 \pm 32.0\end{array}$ & $\begin{array}{c}28 \pm 29.8 \\
21 \pm 22.3 \\
17 \pm 18.1 \\
7 \pm 7.4 \\
21 \pm 22.3\end{array}$ & 0.161 & 6.56 \\
\hline \multicolumn{5}{|l|}{ Marital status } \\
\hline $\begin{array}{l}\text { Single } \\
\text { Married } \\
\text { Widow or divorced }\end{array}$ & $\begin{array}{l}33 \pm 32.4 \\
56 \pm 54.9 \\
13 \pm 12.7\end{array}$ & $\begin{array}{c}39 \pm 40.6 \\
54 \pm 56.3 \\
3 \pm 3.1\end{array}$ & 0.037 & 6.61 \\
\hline \multicolumn{5}{|l|}{ Education } \\
\hline $\begin{array}{l}\text { Illiterate/elementary } \\
\text { High school } \\
\text { University }\end{array}$ & $\begin{array}{l}52 \pm 50.5 \\
23 \pm 22.3 \\
28 \pm 27.2\end{array}$ & $\begin{array}{l}32 \pm 33.3 \\
17 \pm 17.7 \\
47 \pm 49.0\end{array}$ & 0.006 & 10.24 \\
\hline \multicolumn{5}{|l|}{ Residence } \\
\hline $\begin{array}{l}\text { Rural } \\
\text { Urban }\end{array}$ & $\begin{array}{l}35 \pm 34.7 \\
66 \pm 65.3\end{array}$ & $\begin{array}{l}23 \pm 24.0 \\
73 \pm 76.0\end{array}$ & 0.1 & 2.71 \\
\hline \multicolumn{5}{|c|}{ Family history of psychiatric illness } \\
\hline $\begin{array}{l}\text { No } \\
\text { Yes }\end{array}$ & $\begin{array}{l}57 \pm 55.9 \\
45 \pm 44.1\end{array}$ & $\begin{array}{l}79 \pm 82.3 \\
17 \pm 17.7\end{array}$ & $<0.001$ & 16.04 \\
\hline \multicolumn{5}{|l|}{ Alcohol } \\
\hline $\begin{array}{l}\text { No } \\
\text { Yes }\end{array}$ & $\begin{array}{c}99 \pm 95.2 \\
5 \pm 4.8\end{array}$ & $\begin{array}{l}72 \pm 75.8 \\
23 \pm 24.2\end{array}$ & $<0.001$ & 15.46 \\
\hline \multicolumn{5}{|l|}{ Smoking } \\
\hline $\begin{array}{l}\text { No } \\
\text { Yes }\end{array}$ & $\begin{array}{l}58 \pm 55.8 \\
46 \pm 44.2\end{array}$ & $\begin{array}{l}64 \pm 66.7 \\
32 \pm 33.3\end{array}$ & 0.114 & 2.49 \\
\hline \multicolumn{5}{|l|}{ Obesity } \\
\hline $\begin{array}{l}\text { No } \\
\text { Yes }\end{array}$ & $\begin{array}{l}58 \pm 58.6 \\
41 \pm 41.4\end{array}$ & $\begin{array}{l}76 \pm 80.0 \\
19 \pm 20.0\end{array}$ & 0.001 & 10.4 \\
\hline Body weight (kg) & $81.1 \pm 16.5$ & $71.4 \pm 16.4$ & $<0.001$ & 4.09 \\
\hline Height $(\mathrm{cm})$ & $167.3 \pm 9.5$ & $166.2 \pm 8.6$ & 0.391 & 0.86 \\
\hline BMI $\left(\mathrm{kg} / \mathrm{m}^{2}\right)$ & $29.0 \pm 5.6$ & $25.9 \pm 5.7$ & $<0.001$ & 3.85 \\
\hline Waist circumference $(\mathrm{cm})$ & $101.6 \pm 14.0$ & $84.6 \pm 14.4$ & $<0.001$ & 8.42 \\
\hline
\end{tabular}

No any correlations was found between other numerical variables and YKL-40 plasma levels $(p>0.05)$ except for YMRS ( $\mathrm{r}=-0.198 ; p=0.043)$. The ROCanalysis showed that the AUC of YKL-40 in the diagnosis of BD was 0.79 (95\% CI: 0.72-0.85) (Figure 1). When we used 2307.1 as the cutoff level, $82.7 \%$ of all BD-positive samples would be correctly identified using YKL-40 (sensitivity), while $68.1 \%$ of all BD-negative samples would be correctly categorized (specificity). A logistic regression model was built with group (BD versus control) as the dependent variable. YKL-40 (cutoff 2307.1), marital status, and educational level were added to the model as categorical variables, while waist circumference and BMI were included as numerical variables. All variables entered had significant effects on the outcome: YKL-40 $(p<0.001)$, marital status $(p=0.04)$, education $(p=0.03)$, waist circumference $(p<0.001)$, and BMI $(p=0.009)$. The odds ratio (OR) for YKL-40 was calculated as OR=7.4, 95\% CI: 3.1-17.5.

Table 2 - Distribution of the study variables among bipolar disease patients.

\begin{tabular}{lc}
\hline Variables & Mean \pm SD \\
\hline GAF & $76.5 \pm 12.6$ \\
YMRS & $3.6 \pm 4.8$ \\
HDRS & $4.7 \pm 5.1$ \\
CGI-severity & \\
1 & $24 \pm 28.6$ \\
2 & $23 \pm 27.4$ \\
3 & $29 \pm 34.5$ \\
4 & $6 \pm 7.1$ \\
5 & $2 \pm 2.4$ \\
Additional disease & $78 \pm 76.5$ \\
No & $24 \pm 23.5$ \\
Yes & \\
Antipsychotic & $93 \pm 89.4$ \\
No & $11 \pm 10.6$ \\
Yes & \\
Polypharmacy & $11 \pm 10.6$ \\
No & $93 \pm 89.4$ \\
Yes & \\
Antidepressant & $88 \pm 84.6$ \\
No & $16 \pm 15.4$ \\
Yes & \\
Mood modifier & $13 \pm 12.5$ \\
No & $91 \pm 87.5$ \\
Yes & \\
Dual mood modifier & $90 \pm 86.5$ \\
No & $14 \pm 13.5$ \\
Yes & \\
YMRS - young mania rating scale, HDRS - hamilton \\
depression rating scale, GAF - global assessment of functioning \\
\multicolumn{1}{c}{ score, CGI - clinical global impression } \\
\hline
\end{tabular}


Table 3 - YKL-40 levels according to comorbidity and medications.

\begin{tabular}{lccc}
\hline YKL-40 levels & $\begin{array}{c}\text { YKL-40 } \\
\text { Mean } \pm \text { SD }\end{array}$ & t & $P$-value \\
\hline $\begin{array}{l}\text { Comorbidity } \\
\text { No }\end{array}$ & $2730.9 \pm 597.0$ & 0.003 & 0.998 \\
$\quad$ Yes & $2730.6 \pm 343.2$ & & \\
Polypharmacy & & & \\
$\quad$ No & $3072.3 \pm 319.5$ & 2.30 & 0.024 \\
Yes & $2682.3 \pm 551.1$ & & \\
Antidepressants & & & \\
$\quad$ No & $2703.7 \pm 511.7$ & 0.87 & 0.385 \\
Yes & $2832.7 \pm 705.3$ & & \\
Antipsychotics & & & \\
$\quad$ No & $2974.6 \pm 373.4$ & 1.63 & 0.106 \\
Yes & $2693.8 \pm 554.6$ & & \\
Mood modifier & & & \\
$\quad$ No & $2973.1 \pm 452.2$ & 1.79 & 0.077 \\
Yes & $2687.9 \pm 548.6$ & & \\
Dual mood modifier & & & \\
$\quad$ No & $2711.2 \pm 554.5$ & 0.59 & 0.560 \\
Yes & $2802.9 \pm 480.1$ & & \\
\hline
\end{tabular}

Discussion. In this study, the plasma levels of YKL-40 in $\mathrm{BD}$ patients is determined higher than healthy controls. The ROC curve analysis displayed an optimum cutoff point of $>2307.1$ to support that YKL-40 is a useful potential biomarker in BD. Although we had an adequate sample size in this study, there may be some limitations due to study design.

The general limitations of questionnaire studies applies for the demographic questions and the scales. On the other hand, the cases and controls were matched by age and gender to rule out confounding. However, some other confounders may still be present. Calculations of kappa or intraclass correlation (ICC) reliability coefficients could provide estimates regarding the degree of error in the bipolar diagnosis. Besides, the lack of information about the accuracy of the diagnosis can be considered as a weakness in this research. The fact that there is no difference between $\mathrm{BD}$ patients and the occupational distribution of the control group may imply that $\mathrm{BD}$ is not related to the occupations and working lives of patients. The research findings of Adejumo et $\mathrm{al},{ }^{27}$ are similar to the distribution of occupations in our research, where they reported the unemployment rate in $\mathrm{BD}$ patients as $15.5 \%$. The proportion of widow or divorced patients in the $\mathrm{BD}$ group was higher compared to the control group, indicating that BD patients may have difficulties in maintaining their marriages. Adejumo et $\mathrm{al}^{27}$ found

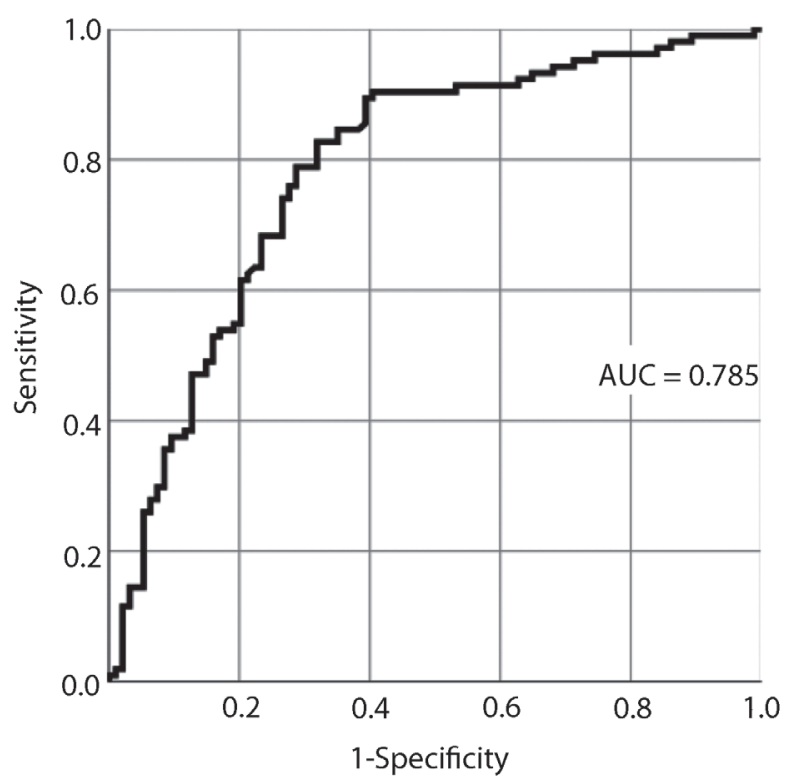

Figure 1 - Receiver operating characteristics analysis of YKL- 40 for differentiating $\mathrm{BD}$ and healthy controls. $\mathrm{BD}$ - bipolar disorder, AUC - area under the curve

18.4\% divorce among BD patients. Also, MetsaSimola et $\mathrm{al}^{28}{ }^{28}$ reported that psychiatric morbidity is a persistent risk factor of divorce. The lower levels of education among $\mathrm{BD}$ patients compared to the control group suggested that $\mathrm{BD}$ adversely affects the education of patients. Although we cannot claim a causal relationship, the lower educational attainment of $\mathrm{BD}$ patients compared to the controls, may be an indicator that BD may adversely affect educational status. On the other hand, a low level of education can make it difficult for patients to benefit from psychoeducation and health education. There is an agreement, that well clinical management of BD patients includes an significant training factor for patients and also for their relatives. ${ }^{29}$ The place of residence of $\mathrm{BD}$ patients was similar to the control group, indicating that settlement is not a risk factor for BD. However, in a large international survey using the internet, the rural residence of $\mathrm{BD}$ patients was reported to be lower (14.9\%) than our study. ${ }^{30}$

Higher rates of psychiatric illnesses in the BD group suggest genetic influences in the etiology of the disease. Jakobsson et $\mathrm{al},{ }^{31}$ found the rate of family history of BD between $29.1 \%$ and $38 \%$. There are many studies supporting the genetic etiology of BD. 3,32,33 The lower rate of alcohol use in $\mathrm{BD}$ patients compared to the control group is important in protecting patients from the neurodegenerative effects of alcohol dependence. 
Although smoking was more prevalent in the BD patients (44.2\%) compare with the healthy controls (33.3\%), the difference was not statistically significant. Wintemberg et $\mathrm{al},{ }^{34}$ reported smoking prevalence in Turkey as $27 \%$. However, in our study, the rate of smoking was higher in both groups. In this study, obesity indicators such as BMI and waist circumference of BD patients were higher than the control group. Ertekin et al, ${ }^{35}$ have found similar alcohol use, smoking, and obesity rates compared to our findings. Obesity is more prevalent in $\mathrm{BD}$ patients compared to the average population. In one study, the prevalence of obesity was found to be $55 \%$ in $\mathrm{BD}$ patients. ${ }^{36}$ The prevalence of obesity in Turkey was found in $28 \%$ of $\mathrm{BD}$ patients. ${ }^{37}$ We found no associations between the presence of comorbidities, use of antidepressants, antipsychotics, mood modifiers, dual mood modifiers, GAF scores, BMI, YMRS, HDRS, or CGI-severity scores and serum YKL-40 levels. However, the reason behind lower YKL-40 levels among patients under polypharmacy requires further elucidation. One meta-analysis has shown increased CRP levels in bipolar disorder regardless of the mood state. ${ }^{38}$ However, our study demonstrated normal levels of CRP in both study and control groups. As to the main outcome measure compared to the controls, YKL-40 concentrations in BD participants were significantly increased. Similarly, YKL-40 concentrations in serum and cerebrospinal fluid (CSF) in BD participants against control group. ${ }^{31}$ YKL-40 serum levels have been adversely affected with manic/hypomanic episodes and with presence of psychotic symptoms. ${ }^{39}$ As a CSF neuroinflammation biomarker, YKL-40 is related with management performance in euthymic bipolar disorder; however, not in control group. ${ }^{40}$

In conclusion, we have observed a strong relationship between YKL- 40 and BD with relatively high predictive power and an OR of above 7 . Thus, we conclude that with acceptable sensitivity and specificity levels, the YKL-40 can be utilized as a marker in the diagnosis and follow-up of BD. Future research should concentrate on testing and confirming the YKL- 40 as a marker in different contexts and patient populations.

Acknowledgment. The authors gratefully acknowledge Hülya Ertekin, MD, for her contributions, and ailem ${ }^{\oplus}$ Academic Counseling Services (www.aile.net), Izmir, Turkey for their rigorous editing and language correction of this manuscript.

\section{References}

1. Price AL, Marzani-Nissen GR. Bipolar disorders: a review. Am Fam Physician 2012; 85: 483-493.
2. Leopold K, Reif A, Haack S, Bauer M, Bury D, Löffler A, et al. Type 2 diabetes and pre-diabetic abnormalities in patients with bipolar disorders. J Affect Disord 2016; 189: 240-245.

3. Baum AE, Akula N, Cabanero M, Cardona I, Corona W, Klemens B, et al. A genome-wide association study implicates diacylglycerol kinase eta (DGKH) and several other genes in the etiology of bipolar disorder. Mol Psychiatry 2008; 13: 197-207.

4. Hashimoto K, Sawa A, Iyo M. Increased levels of glutamate in brains from patients with mood disorders. Biol Psychiatry 2007; 62: 1310-1316.

5. Houenou J, Frommberger J, Carde S, Glasbrenner M, Diener C, Leboyer M, et al. Neuroimaging-based markers of bipolar disorder: evidence from two meta-analyses. J Affect Disord 2011; 132: 344-355.

6. Barnett JH, Huang J, Perlis RH, Young MM, Rosenbaum JF, Nierenberg AA, et al. Personality and bipolar disorder: dissecting state and trait associations between mood and personality. Psychol Med 2011; 41: 1593-1604.

7. Chaudron LH, Pies RW. The relationship between postpartum psychosis and bipolar disorder: a review. J Clin Psychiatry 2003; 64: 1284-1292.

8. Merikangas KR, Jin R, He JP, Kessler RC, Lee S, Sampson NA, et al. Prevalence and correlates of bipolar spectrum disorder in the world mental health survey initiative. Arch Gen Psychiatry 2011; 68: 241-251.

9. Hakala BE, White C, Recklies AD. Human cartilage gp-39, a major secretory product of articular chondrocytes and synovial cells, is a mammalian member of a chitinase protein family. $J$ Biol Chem 1993; 268: 25803-25810.

10. Shackelton LM, Mann DM, Millis AJ. Identification of a $38-\mathrm{kDa}$ heparin-binding glycoprotein (gp38k) in differentiating vascular smooth muscle cells as a member of a group of proteins associated with tissue remodeling. J Biol Chem 1995; 270: 13076-13083.

11. Rehli M, Krause SW, Andreesen R. Molecular characterization of the gene for human cartilage gp-39 (CHI3L1), a member of the chitinase protein family and marker for late stages of macrophage differentiation. Genomics 1997; 43: 221-225.

12. Rolstad S, Jakobsson J, Sellgren C, Ekman CJ, Blennow K, Zetterberg $\mathrm{H}$, et al. Cognitive performance and cerebrospinal fluid biomarkers of neurodegeneration: a study of patients with bipolar disorder and healthy controls. PLoS One 2015; 10 : e0127100.

13. Hellwig K, Kvartsberg H, Portelius E, Andreasson U, Oberstein TJ, Lewczuk P, et al. Neurogranin and YKL-40: independent markers of synaptic degeneration and neuroinflammation in Alzheimer's disease. Alzheimers Res Ther 2015; 7: 74.

14. Bonneh-Barkay D, Bissel SJ, Kofler J, Starkey A, Wang G, Wiley CA. Astrocyte and macrophage regulation of YKL-40 expression and cellular response in neuroinflammation. Brain Pathol 2012; 22: 530-546.

15. Craig-Schapiro R, Perrin RJ, Roe CM, Xiong C, Carter D, Cairns NJ, et al. YKL-40: a novel prognostic fluid biomarker for preclinical Alzheimer's disease. Biol Psychiatry 2010; 68: 903-912.

16. Bonneh-Barkay D, Zagadailov P, Zou H, Niyonkuru C, Figley M, Starkey A, et al. YKL-40 expression in traumatic brain injury: an initial analysis. J Neurotrauma 2010; 27: 1215-1223.

17. Zhang W, Kawanishi M, Miyake K, Kagawa M, Kawai N, Murao K, et al. Association between YKL-40 and adult primary astrocytoma. Cancer 2010; 116: 2688-2697. 
18. Bonneh-Barkay D, Wang G, Starkey A, Hamilton RL, Wiley CA. In vivo CHI3L1 (YKL-40) expression in astrocytes in acute and chronic neurological diseases. J Neuroinflammation 2010; 7: 34 .

19. Frye MA, Nassan M, Jenkins GD, Kung S, Veldic M, Palmer $\mathrm{BA}$, et al. Feasibility of investigating differential proteomic expression in depression: implications for biomarker development in mood disorders. Transl Psychiatry 2015; 5: e689.

20. Von Elm E, Altman DG, Egger M, Pocock SJ, Gøtzsche PC, Vandenbroucke JP. The Strengthening the Reporting of Observational Studies in Epidemiology (STROBE) statement: Guidelines for reporting observational studies. PLoS Med 2007; 4: e296.

21. American Psychiatric Association. Task Force on DSM 5. Diagnostic and Statistical Manual of Mental Disorders DSM-5. DSM-5; 2013. p. 991.

22. Young RC, Biggs JT, Ziegler VE, Meyer DA. A rating scale for mania: reliability, validity and sensitivity. Br J Psychiatry 1978; 133: 429-435.

23. Akdemir A, Türkçapar MH, Orsel SD, Demirergi N, Dag I, Ozbay MH. Reliability and validity of the Turkish version of the Hamilton Depression Rating Scale. Compr Psychiatry 2001; 42: 161-165.

24. Hall RC. Global assessment of functioning. A modified scale. Psychosomatics 1995; 36: 267-275.

25. Karadağ F, Oral T, Yalçin FA, Erten E. [Reliability and validity of Turkish translation of Young Mania Rating Scale]. Turk Psikiyatri Derg 2002; 13: 107-114. [Turkish]

26. Busner J, Targum SD. The clinical global impressions scale: applying a research tool in clinical practice. Psychiatry (Edgmont) 2007; 4: 28-37.

27. Adejumo AO, Ikoba NA, Suleiman EA, Okagbue HI, Oguntunde PE, Odetunmibi OA, et al. Quantitative exploration of factors influencing psychotic disorder ailments in Nigeria. Data Brief 2017; 14: 175-185.

28. Metsä-Simola N, Martikainen P, Monden CW. Psychiatric morbidity and subsequent divorce: a couple-level register-based study in Finland. Soc Psychiatry Psychiatr Epidemiol 2018; 53 : 823-831.

29. Goodwin GM, Haddad PM, Ferrier IN, Aronson JK, Barnes T, Cipriani A, et al. Evidence-based guidelines for treating bipolar disorder: Revised third edition recommendations from the British Association for Psychopharmacology. J Psychopharmacol 2016; 30: 495-553.
30. Conell J, Bauer R, Glenn T, Alda M, Ardau R, Baune BT, et al. Online information seeking by patients with bipolar disorder: results from an international multisite survey. Int J Bipolar Disord 2016; 4: 17.

31. Jakobsson J, Bjerke M, Sahebi S, Isgren A, Ekman CJ, Sellgren $\mathrm{C}$, et al. Monocyte and microglial activation in patients with mood-stabilized bipolar disorder. J Psychiatry Neurosci 2015; 40: 250-258.

32. Sklar P, Smoller JW, Fan J, Ferreira MA, Perlis RH, Chambert $\mathrm{K}$, et al. Whole-genome association study of bipolar disorder. Mol Psychiatry 2008; 13: 558-569.

33. Wellcome Trust Case Control Consortium. Genome-wide association study of 14,000 cases of seven common diseases and 3,000 shared controls. Nature 2007; 447: 661-678.

34. Wintemberg J, Yu M, Caman OK. Health Warnings, Smoking Rules, and Smoking Status: A Cross-National Comparison of Turkey and the United States. Subst Use Misuse 2018; 53 : 963-971.

35. Ertekin H, Sahin B, Caliskan AM, Inanli I, Ertekin YH. Metabolic syndrome and vaspin in patients with bipolar disorder. Kaohsiung J Med Sci 2018; 34: 522-528.

36. Hsu JH, Chien IC, Lin CH. Increased risk of hyperlipidemia in patients with bipolar disorder: a population-based study. Gen Hosp Psychiatry 2015; 37: 294-298.

37. Genc A, Kalelioglu T, Tasdemir A, Genc ES, Ozver I, Yesilbas $\mathrm{D}$, et al. The prevalence of metabolic syndrome parameters among bipolar disorder outpatients on lithium monotherapy. Klin Psikofarmakol Bul 2012; 22: 320-324.

38. Fernandes BS, Steiner J, Molendijk ML, Dodd S, Nardin P, Gonçalves CA, et al. C-reactive protein concentrations across the mood spectrum in bipolar disorder: a systematic review and meta-analysis. Lancet Psychiatry 2016; 3: 1147-1156.

39. Isgren A, Sellgren C, Ekman CJ, Holmén-Larsson J, Blennow $\mathrm{K}$, Zetterberg $\mathrm{H}$, et al. Markers of neuroinflammation and neuronal injury in bipolar disorder: Relation to prospective clinical outcomes. Brain Behav Immun 2017; 65: 195-201.

40. Rolstad S, Jakobsson J, Sellgren C, Isgren A, Ekman CJ, Bjerke $\mathrm{M}$, et al. CSF neuroinflammatory biomarkers in bipolar disorder are associated with cognitive impairment. Eur Neuropsychopharmacol 2015; 25: 1091-1098. 